УДК: 658.1

JEL Classification: M 21

Н. Й. РАДІОНОВА,

кандидат економічних наук,

доиент кафедри обліку і аудиту,

Київський начіональний університет технологій та дизайну

\title{
Теоретико-методичні аспекти розроблення стратегії управління затратами на промисловому підприємстві
}

У статті розглянуто основні стратегічні завдання, які стоять перед промисловим підприємством. Представлено схему зв 'язків міз ирілями і базовими компонентами розроблення стратегії управління затратами на підприємстві. Показано залежності між затратами та випуском продукиії і прибутковістю. Розглянуто вплив співвідношення між постійними $і$ змінними затратами на положення точки беззбитковості. Показано механізм розрахунку прибутковості одиниці продукиії. Наочно представлено систему стратегічного управління затратами промислового підприємства.

Ключові слова: промислове підприємство, управління затратами, стратегія управління, випуск продукиії, постійні затрати, змінні затрати.

Постановка проблеми та ії̈ зв'язок із важливими науковими та практичними завданнями. Сучасний рівень економічного розвитку зумовлює необхідність не лише в управлінні промисловим підприємством, а й у розробленні загального напряму розвитку за умов впливу непередбачуваних подій і чинників. Враховуючи різні аспекти планування діяльності промислового підприємства найважливішим є процес управління затратами, тобто процес дослідження і прийняття управлінських рішень на всіх основних етапах формування і розподілу доходів та здійснення витрат на промисловому підприємстві. Управління затратами, яке забезпечує ефективність діяльності, фінансову та економічну стійкість промислового підприємства на ринку, посідає особливе місце у системі стратегічного управління підприємством. Це обумовлює актуальність досліджень, присвячених теоретико-методичним питанням розроблення стратегії управління затратами на промисловому підприємстві.

Аналіз останніх досліджень і публікацій. Як свідчить аналіз останніх публікацій, загальні питання управління затратами підприємства знайшли висвітлення у працях вітчизняних і зарубіжних науковців-економістів, серед яких Д. Аакер [1], Т. І. Адирова [2], М. П. Денисенко [3], С. Б. Хаустова [3], Г. А. Дощич [4], Г. Я. ІльницькаГикавчук [5], Г. В. Козаченко [6], М. І. Скрипник [7], М. М. Матюха [1]. Проте широке коло питань теоретико-методологічного та прикладного характеру, пов'язаних із розробленням стратегії управління затратами на виробничому підприємстві, не отримало достатньо повного і системного відображення у вітчизняній науковій літературі, що потребує подальших досліджень з цієї тематики.

Метою дослідження є теоретичне обгрунтування методичних аспектів розроблення стратегії управління затратами на промисловому підприємстві.

Виклад основного матеріалу дослідження. У разі відсутності необхідної інформації керівники часто приймають рішення інтуїтивно, відтак підвищуючи ризик прийняття неправильного рішення. Тож на сьогоднішній день існує об'єктивна необхідність вдосконалення систем і методів стратегічного управління промисловим підприємством, зокрема стратегії управління затратами. Стратегії передбачають сукупність заходів із великою тривалістю реалізації. Тому розроблення стратегії управління затратами повинно грунтуватися на завданнях, які складають основу загальної стратегії розвитку підприємства. Такими завданнями можуть бути:

- завдання оновлення продукції, що випускається промисловим підприємством, з урахуванням попиту;

- завдання оновлення технології виробництва на базі сучасних технологій;

- завдання залучення інвестицій [1].

() Н. Й. Радіонова, 2018 
Аналітичним інструментарієм управління затратами є методи і моделі, які забезпечують вирішення цих завдань при підтримці такого рівня затрат, який дозволить досягти бажаного прибутку на кожному окремому етапі розвитку промислового підприємства. Для цього, перш за все, потрібно забезпечити певну функціональну залежність між затратами та іншими компонентами економічного механізму діяльності промислового підприємства: обсягом виробництва продукції, фінансовими ресурсами, прибутком.

Зв'язок між цілями та комплексом базових компонентів розроблення стратегії управління затратами на промисловому підприємстві у загальному вигляді представлено на рис. 1.

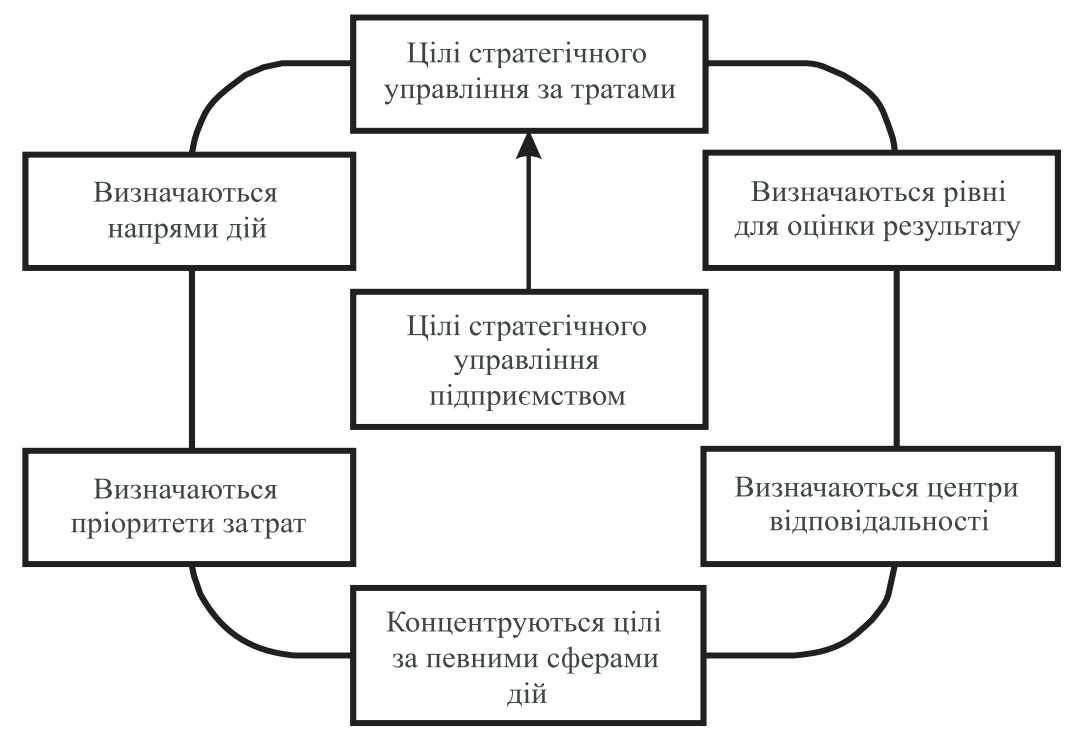

Рис. 1. Схема зв'язків між цілями і базовими компонентами розроблення стратегії управління затратами на промисловому підприємстві

Джерело: розробка автора

Найважливішим чинником в управлінні підприємством взагалі та управлінні затратами зокрема $є$ встановлення правильної залежності між затратами та ресурсами для забезпечення випуску за таких затрат певного обсягу продукції за фіксований час. Таку залежність можна виразити формулою [5]:

$$
\mathrm{Q}=\frac{\mathrm{K}_{\phi}+\mathrm{B}_{\mathrm{p}}-3_{\text {пост }}}{3_{\text {змін }}}
$$

де Q - обсяг випуску продукції;

$K_{\phi}-$ фінансові кошти підприємства (власні плюс позикові кошти);

$\mathrm{B}_{\mathrm{p}}^{\phi}$ - виручка від продажу продукції;

$3_{\text {пост }}{ }^{p}$-постійні затрати на одиницю продукції;

$3_{\text {змін }}$ - змінні затрати на одиницю продукції.

При $\mathrm{Q}<\mathrm{Q}_{\text {мах }}$ (максимальний обсяг випуску) в 2 і більше разів або $\mathrm{Q}<\mathrm{Q}_{\text {бв }}$ (обсяг беззбиткового виробництва) і $\mathrm{K}_{\phi}=$ const слід вживати оперативних заходів щодо зниження $3_{\text {пост }}$ або $3_{\text {змін, }}$ або і тих й інших.

За неможливості зниження затрат 3 пост і $3_{\text {змін }}$ потрібні термінові заходи із залучення позикових коштів (додаткових кредитів).

Стосовно затрат випуск продукції може бути здійснений за двома принципами [4]: 3 високим рівнем постійних затрат 3 пост $і$ більш низьким рівнем змінних затрат $3_{\text {змін }}$ на одиницю продукції;

з низьким рівнем постійних затрат $3_{\text {пост }}$ і більш високим рівнем змінних затрат $3_{\text {змін }}$ на одиницю продукції. 
Технологія з високим рівнем постійних затрат передбачає зосередження на промисловому підприємстві всіх стадій виробничого процесу - від заготівельної до складської.

Технологія з низьким рівнем постійних затрат передбачає схему, близьку до технології складського підприємства.

Вибір того чи іншого виду технології виробництва продукції за чинником затрат проводиться з урахуванням ступеня впливу співвідношення між постійними та змінними затратами.

При виборі технології виробництва слід враховувати і чинник стійкості попиту на продукцію. Чим більше тривалість попиту, тим більш економічно ефективною буде технологія за постійними затратами, оскільки від тривалості попиту залежить тривалість перебування продукції у серійному виробництві. Отже, тут проявляється закономірність економії на масштабі, згідно з якою постійні затрати на одиницю продукції зменшуються зі збільшенням обсягу іiї випуску, тобто внаслідок розподілу постійних затрат на більший обсяг продукції [7].

За своєю сутністю постійні затрати пов'язані зі створенням і функціонуванням основних виробничих засобів підприємства, їх обслуговуванням, ремонтом, опаленням, орендою, заробітною платою виробничого персоналу тощо. Отже, відношення постійних затрат до змінних залежить не тільки від обсягу випуску продукції, а й від ступеня використання основних засобів. А обсяг випуску продукції не може бути незалежним від віддачі основних засобів, що відображає формула [6].

$$
3_{\text {пост }}=\mathrm{q} \times 3_{\text {змін }}
$$

де q - обсяг випуску продукції, при якому виручка від реалізації продукції дорівнює затратам.

Наведена вище залежність (2) є капіталозатратами на одну гривню основних засобів. Чим нижче цей показник, тим більш ефективними є технології виробничого процесу випуску продукції і організації праці. При незабезпеченні раціонального рівня капіталозатрат може виникнути небажана ситуація в ціновій політиці підприємства, коли внаслідок високих постійних і змінних затрат єдиним виходом буде підвищення ціни, що може привести підприємство до катастрофічного економічного становища. Тому при розробленні стратегії управління потрібно розв'язати задачу оптимальної відповідності між залежністю (2) і відносною ціною для досягнення певної (запланованої) величини прибутку. Але потрібно також врахувати те, що поліпшення використання виробничих ресурсів веде до зменшення змінних затрат на одиницю продукції. Зменшення змінних затрат відбувається внаслідок відносного зменшення загального часу на обслуговування виробництва, зниження трудозатрат при тривалому періоді перебування продукції в серійному виробництві. 3 ефекту серійності виробництва за затратами слідують важливі висновки для економічного управління підприємством: часта заміна продукції, що випускається, невигідна підприємству; підприємство повинно вживати заходів для забезпечення більш тривалого життєвого циклу продукції через подовження терміну іiї перебування в серійному виробництві.

Врахування всіх розглянутих та інших чинників впливає на прибутковість промислового підприємства, проте їх вплив на прибуток може бути різним.

Іноді, навіть за нібито сприятливих умов, вплив різних чинників на затрати може приводити до недоотримання або повної відсутності прибутку [3]. Так, при певних сумарних затратах підприємство може мати і збитки, якщо ці затрати перевищуватимуть виручку. Якщо затрати дорівнюватимуть виручці, забезпечується лише беззбитковість продукції і промислове підприємство не матиме прибутку. Підприємство стає прибутковим, якщо виручка перевищує сумарні затрати. Прибутковість однієї одиниці продукції $\mathrm{P}_{\mathrm{i}}$ можна розрахувати за формулою [5]:

$$
\mathrm{P}_{\mathrm{i}}=\left(Ц-3_{\text {змін }}\right)-3_{\text {пост }}: \mathrm{Q}
$$

Ц - ціна одиниці продукції.

Із залежності (3) видно, що зміна прибутку на одиницю продукції за сталої ціни можлива через впровадження в стратегію управління затратами заходів, що корегують сумарну величину затрат за однією з ії складових або за двома складовими одночасно. 
Зважаючи на комплекс факторів, що впливають на затрати, при розробленні стратегії управління затратами на підприємстві необхідно насамперед передбачити системність і узгодженість дій, що забезпечить необхідні параметри ефективності (рис. 2).

Велику роль при виборі стратегії управління затратами на підприємстві відіграють властивості продукції, що впливають на іiі комерціалізацію. Об’єктивно оцінити ці властивості можливо за допомогою методу управління затратами - таргет-костинг.

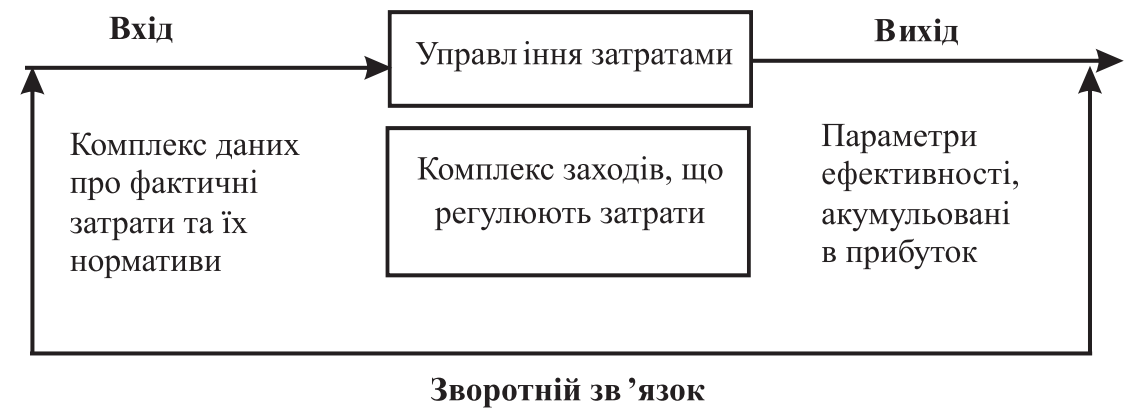

\section{Рис. 2. Система стратегічного управління затратами на підприсмстві}

Джерело: розробка автора

Метою системи таргет-костинг є створення нової продукції, конкурентоспроможної за ціною. Для цього визначаються:

- функції, властивості і якість продукції, яким споживачі віддають найбільшу перевагу;

- можливі ціна реалізації та обсяги реалізації продукції [2].

Особливість методу таргет-костинг полягає в проведенні функціонального аналізу продукції та визначенні на основі його результатів здатності продукції бути конкурентоспроможною.

Цей метод також передбачає вивчення пріоритетних для покупця споживчих властивостей продукції, тобто визначення тієї чи іншої функції продукції для масового споживача за допомогою встановлення “зони корисності” продукції і впливу конкретної властивості продукції на загальну ії оцінку. Чим менше розходяться показники “зони корисності” продукції у покупців, тим більш однорідними є їх вимоги до продукції і тим легше визначити їх потребу в продукції.

Потім вирішується завдання встановлення можливих обсягів реалізації та можливої ціни реалізації. Для цього визначаються допустимі затрати на виробництво продукції. Загальна сума допустимих затрат включає всі затрати, які можуть виникнути протягом усього життєвого циклу продукції. Для отримання більш точного результату потрібно розподілити суму допустимих затрат за сферами діяльності на підприємстві (виробництво, маркетинг, збут, управління).

Далі визначається, які види діяльності, які компоненти продукції і якою мірою впливають на реалізацію певних функцій або властивостей продукції, якій віддають перевагу споживачі. При відповіді на це питання $\epsilon$ небезпека неправильної оцінки ролі того чи іншого компонента в реалізації функцій, оскільки деякі функції можна лише умовно віднести на той чи інший компонент продукції.

Висновки. Управління затратами можна визначити як взаємопов'язаний комплекс робіт щодо формування і контролю затрат під час здійснення господарської діяльності, які спрямовані на досягнення оптимального рівня затрат в усіх підсистемах промислового підприємства.

Розглянуто основні стратегічні завдання, що стоять перед промисловим підприємством; зв'язки між цілями і базовими компонентами розроблення стратегії управління затратами на підприємстві; залежності між затратами та випуском продукції і прибутковістю, вплив співвідношення між постійними і змінними затратами на положення точки беззбитковості; механізм розрахунку прибутковості одиниці продукції; стратегічного управління затратами промислового підприємства. Результати 
дослідження доводять, що правильно обрана стратегія управління затратами на промисловому підприємстві $є$ одним із важливих шляхів забезпечення його розвитку та конкурентоспроможності на ринку.

\section{Список використаних джерел}

1. Аакер Д. Стратегическое рыночное управление. Пер. с англ. СПб.: Питер, 2007. $496 \mathrm{c.}$

2. Адирова Т. І. Система управління витратами - target-costing на машинобудівних підприємствах // Економіка та держава. 2012. № 7. С. 82-84.

3. Денисенко М. П., Хаустова Є. Б. Аналіз інтелектуального капіталу та його складових за показниками модифікованого балансу // Проблеми інноваційно-інвестиційного розвитку. 2017. № 4. С. 12-20.

4. Дощич Г. А. Дослідження актуальних проблем управління витратами підприємства [Електронний ресурс] / Вінницький торговельно-економічний інститут. URL: http:// www.rusnauka.com/29_DWS_2012/Economics/10_120778.doc.htm.

5. Ільницька-Гикавчук $\bar{\Gamma}$. Я., Щур О. М. Удосконалення управління витратами підприємства // Вісник Хмельницького національного університету. Економічні науки. 2012. № 6. Т. 1. С. 94-96.

6. Козаченко Г. В., Погорелов Ю. С., Макухін Г. А. Управління затратами підприємства: моногр. К.: Лібра, 2007. 320 с.

7. Скрипник М. І. Радіонова Н. Й., Матюха М. М. Імплементація стратегічного управлінського обліку на промислових підприємствах // Проблеми теорії та методології бухгалтерського обліку, контролю і аналізу. Міжнар. зб. наук пр. Серія: Бух. облік, контроль і аналіз. Житомир: ЖДТУ, 2015. Вип. 2(32). С. 330-342.

\section{References}

1. Aaker D. (2007). Strategicheskoe ryinochnoe upravlenie [Strategic market management]. Translated from English. S.-Petersburg: Piter [in Russian].

2. Adyrova T. I. (2012). Systema upravlinnia vytratamy - target-costing na mashynobudivnykh pidpryiemstvakh. [The cost management system - target-costing at engineering enterprises]. Ekonomika ta derzhava - The economy and the state, 7, 82-84 [in Ukrainian].

3. Denysenko M. P., Khaustova Ye. B. (2017). Analiz intelektualnoho kapitalu ta yoho skladovykh za pokaznykamy modyfikovanoho balansu [Analysis of the intellectual capital and its components by data from the modified balance]. Problemy innovatsiinoinvestytsiinoho rozvytku - Problems of the innovation and investment driven development, 4. 12-20 [in Ukrainian].

4. Doshchych H. A. Doslidzhennia aktualnykh problem upravlinnia vytratamy pidpryiemstva [Studying important problems in cost management of an enterprises]. Vinnytsia Institute of Trade and Economics [Electronic resources]. URL: http://www.rusnauka. com/29_DWS_2012/Economics/10_120778.doc.htm [in Ukrainian].

5. Ilnytska-Hykavchuk H. Ya., Shchur O. M. (2012). Udoskonalennia upravlinnia vytratamy pidpryiemstva [Improving cost management at an enterpise]. Visnyk Khmelnytskoho natsionalnoho universytetu. Ekonomichni nauky - Bulletin of Khmelnitsk National University. Economics, 6(1), 94-96 [in Ukrainian].

6. Kozachenko H. V., Pohorelov Yu. S., Makukhin H. A. (2007). Upravlinnia zatratamy pidpryiemstva [Cost management at an enterpise]. Kyiv: Libra [in Ukrainian].

7. Skrypnyk M. I. Radionova N. Y., Matiukha M. M. (2015). Implementatsiia stratehichnoho upravlinskoho obliku na promyslovykh pidpryiemstvakh [Implementing strategic management accounting at industrial enterprises]. Problemy teorii ta metodolohii bukhhalterskoho obliku, kontroliu i analizu. Seriia: Bukh. oblik, kontrol i analiz-Problems of theory and methodology of accounting, control and analysis. Series: Accounting, control and analysis, 2(32), 330-342 [in Ukrainian]. 
Н. Й. РАДИОНОВА, кандидат экономических наук, доиент кафедры учета и аудита, Киевский национальный университет технологий и дизайна

\section{Теоретико-методические аспекты разработки стратегии управления затратами на промышленном предприятии}

В статье рассмотрены основные стратегические задачи, стоящие перед промылиленным предприятием. Представлена схема связей между изелями и базовыми компонентами разработки стратеги управления затратами на предприятии. Показаны зависимости между затратами, выпуском продукиии и прибыльностью. Рассмотрено влияние соотношения между постоянными и переменными затратами на положение точки безубыточности. Показан механизм расчета доходности единиць продукиии. Наглядно представлена система стратегического управления затратами промышленного предприятия.

Ключевые слова: промышленное предприятие, управление затратами, стратегия управления, выпуск продукиии, постоянные затраты, переменные затраты.

N. Y. RADIONOVA, PhD (Economics),

Associate Professor of Accounting and Audi t Department, Kyiv National University for Technology and Design

\section{Building Cost Management Strategy at Industrial Enterprise: Theoretical and Methodical Aspects}

Cost management is a central issue in business planning at industrial enterprises, because it contributes to business performance, financial and economic stability of an industrial enterprise at the market. This raises the importance of studies devoted to theoretical and methodic aspects of cost management strategy at industrial enterprises. The article aims to provide theoretical substantiation to methodical aspects of cost management strategy at an industrial enterprise.

Cost management can be defined as a complex of efforts related with the formation and control of costs in course of business operation, aiming at optimization of costs in all the subsystems of an industrial enterprise.

Subject to analysis is a set of strategic tasks to be addressed by an industrial enterprise; links between goals and basic components of cost management strategy at an industrial enterprise; correlations between costs, output and profit rates, effects of the ratio of fixed costs to variable costs for the break-even position; the algorithm for calculating the unit profitability. Product features with commercialization effects have essential role in selecting a cost management strategy; they can be assessed by target costing, which detailed review is given. The study demonstrates that a cost management strategy at an industrial enterprise, once properly selected, will be an important factor for its performance and market competitiveness.

Keywords: industrial enterprise, cost management, strategy of management, production output, fixed costs, variable costs.

\section{Посилання на статтю:}

Радіонова Н. Й. Теоретико-методичні аспекти розроблення стратегії управління затратами на промисловому підприємстві // Науковий вісник Національної академії статистики, обліку та аудиту: зб. наук. пр. 2018. №1-2. С. 182-187. 